\title{
Khrebtov 0. INVESTIGATION OF ELECTROCONTACT ANNEALING IN THE PRODUCTION PROCESS OF STEEL WELDING WIRE
}

\begin{abstract}
Розглянуто результати експериментальних і теоретичних досліджень щодо визначення умов реалізації електроконтактного відпалу в процесі виробництва сталевого зварювального дроту. Показано вплив прямого нагріву струмом на формування структури $і$ зміни механічних властивостей зварювального дроту СВ08Г2С. За допомогою експериментальної установки електроконтактного нагріву отримані проміжні значення параметрів дроту, що задовольняють умовам подальшої обробки дроту одночасно з відповідністю до вимог якості, що висуваються до готової продукцї.
\end{abstract}

Ключові слова: сталевий зварювальний дріт, електроконтактний відпал, механічні властивості зварювального дроту.

\section{Introduction}

The output of steel welding wire occupies $9-11 \%$ of the total steel production in Ukraine [1,2]. The production of a welding wire is performed by drawing steel wire to the required diameter at multiple drawing mills, followed by coppering the resulting wire in the final production operations [3].

To ensure the proper level of quality during the wire production process, namely - to prevent and reduce the number of breaks during drawing - an intermediate wire annealing operation of diameters of $2 \mathrm{~mm}$ and $2.5 \mathrm{~mm}$ is used. At this transition, the drawing of steel wire to the required diameter before the reduction of copper due to the formed «work hardening» is accompanied by frequent breaks, hence, the stops of the mills. The relevance of research is study of the application of an additional annealing operation to reduce the abruption probability. This annealing will remove all internal stresses formed in the metal during the previous drawing, which will allow obtaining a homogeneous fine-grained internal structure of the wire.

\section{The object of research and its technological audit}

The object of research is the use of electrocontact annealing in the production process of steel welding wire.

From the theoretical studies of the mechanical properties of electric annealed steel, it is known that the hardness of steel annealed by electric heating at the appropriate temperatures is higher than the hardness of steel annealed in the furnace [4]. In addition, with an electric tempering in a certain temperature range, the high strength characteristics of steel are combined with its satisfactory plasticity [5]. Thus, electro-tempered steel is a high-strength structural material with a combination of strength and ductility that can't be achieved with tempering in the furnace. Therefore, the use of direct electric contact heating (EH) instead of the previously used heating in the furnace allows to get rid of the listed disadvantages.

In the production of welding wire by electrocontact annealing, despite all the obvious EH advantages, its use in the production of welding wire is difficult. This is due to the lack of such equipment in the Ukrainian market and modern technological solutions for its implementation, in accordance with the realities of production conditions [6].

The requirements to the mechanical parameters of the wire after this annealing are not defined, which should ensure simultaneously the stability of the further drawing process with copper plating and the conformity of the GOST to the products obtained [7]. Without addressing these issues, EH introduction in the production of welding wire is difficult.

\section{The aim and objectives of research}

The aim of research is quality improvement of steel welding wire by using electrocontact annealing with special equipment.

To achieve this aim, it is necessary to solve such problems:

1. To develop an optimal layout of the electrocontact rollers with respect to the wire with the possibility of their cooling.

2. To determine the values of the mechanical parameters of the steel wire after electrocontact annealing, which simultaneously satisfies the stability of the further drawing process with copper plating and the conformity of the advanced GOST to obtained products.

3. To confirm the necessity of using the automatic temperature control system for electrocontact annealing.

\section{Research of existing solutions of the problem}

It is necessary to ensure the parameters of the heat treatment of the output products in such way that to 
improve the quality and productivity of the steel welding wire at minimal cost.

As a result of the analysis of literature data [3-7], methods for performing technological operations with continuously cast and rolled wires of different materials are established. The calculated and experimental dependences of the influence of the drawing regimes on the final properties of the wire are obtained. An analysis of the influence of wire production method on the physical and mechanical characteristics of the obtained material is also carried out [8-10].

The effect of $0-10 \%$ voltage application and $300-$ $600{ }^{\circ} \mathrm{C}$ heat treatment for $2-30$ minutes of NiTi wire in a salt bath with subsequent rapid quenching is studied. When applying this technique, the modulus of elasticity is highly inconsistent and reduces the quality of products [11].

The use of thermal annealing to improve the operability of an object for a particular technological process, namely, the restoration of conical surfaces of parts by electrocontact welding by wire, is also considered in [12]

The authors of [13] show that the improvement of the microstructure and properties of the $\mathrm{Ag}-4 \mathrm{Pd}$ alloy wire after drawing and heat treatment can be achieved by controlling the drawing speed and the heat treatment temperature, i. e., the melting current of the Ag-4Pd alloy compound. These parameters also affect the mechanical properties and structure of the alloy.

In work [14] for mathematical modeling of electrocontact annealing process, the questions of mathematical calculation of the distribution of the temperature field as a function of heat sources are considered.

Thus, the results of the analysis lead to the conclusion that in order to improve the quality of products, it is necessary to conduct research in the field of heat treatment of wire when drawing, both on single and multiple drawing mills.

\section{Methods of research}

To solve the problems, a previously designed and implemented experimental wire annealing unit with an automatic temperature control system at the measured point is used [15]. The structural arrangement of the current-conducting contact rollers of this unit is shown in Fig. 1. Heating for obtaining two heating zones is carried out using three rollers, while the heating temperature is distributed into zones. This allows to reduce the voltage in the heating zone of the wire. The separation of the heating section into two zones allows the heating to be divided into temperature ranges in the first section up to $180-250{ }^{\circ} \mathrm{C}$ (pre-heating condition) and in the second up to $500-600{ }^{\circ} \mathrm{C}$ (within the optimal technological mode) [16].

An additional element that increases the stability of the mechanical part of the unit when passing through it wires are the dies installed in front of the roller 1, 2 (Fig. 1). This technical solution prevents slipping of the wire from the grooves of rollers 1, 2, 3 (Fig. 1). The use of a die at the inlet of the unit results in the straightening of the incoming wire, which is positively displayed during the annealing process. To prevent slipping of the wire, special grooves are provided, along which the movement of the wire «fixes».

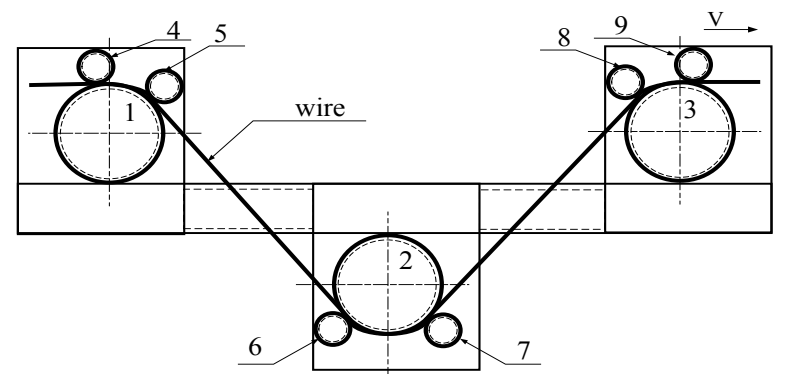

Fig. 1. Schematic layout of electrocontact rollers with respect to the wire: $1,2,3(\varnothing=170 \mathrm{~mm})$ - the rollers are current-conducting; 4, 5, 6, 7, 8, 9 - the rollers perform the pressing (guiding) function

To increase the wear resistance, the current-conducting rollers are made of: roller 1, 3 - tungsten-cobalt (TC), roller 2 - titanium-nickel (TN). Using rollers made of this alloy increases the working time of the process unit due to its high wear resistance. In addition, the possibility of cooling the rollers is realized. Cooling is performed using a passing cooling liquid through special chambers constructed in a block of rollers. Circulation of cooling liquid is carried out by means of application of the pump in the cooling system. The used electrocontact annealing unit is shown in Fig. 2.

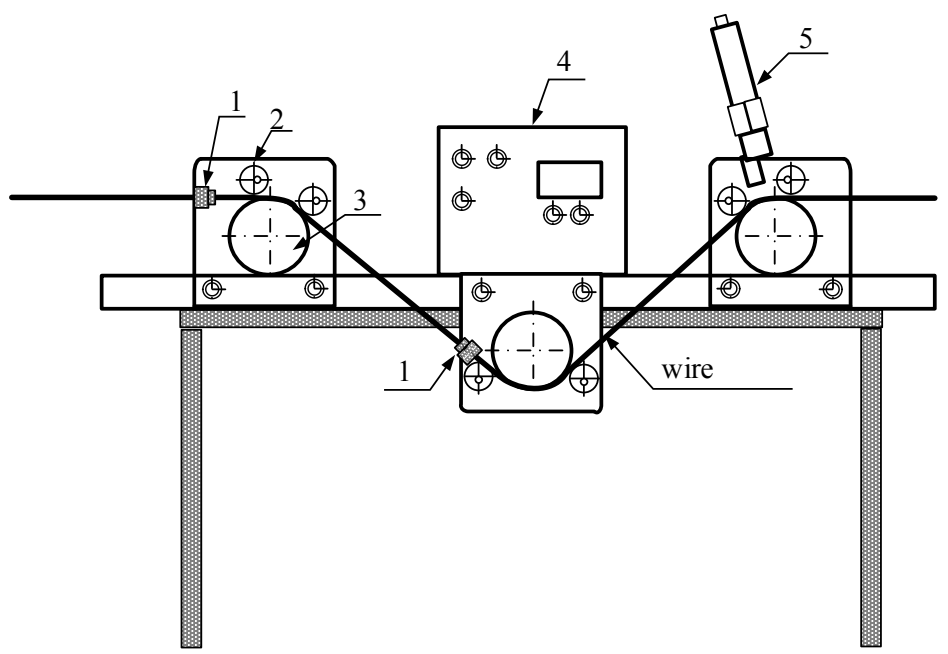

Fig. 2. Experimental annealing unit: 1 - guide die; 2 - clamping roller; 3 - contact raller; 4 - contral cabinet; 5 - pyrameter

As a current source, a transformer is used, which ensures the passage of an alternating current sufficient for a heating temperature of $500-650{ }^{\circ} \mathrm{C}$ at a wire annealing rate of $1 \mathrm{~m} / \mathrm{s}$.

To improve the quality of the annealed wire, namely, by the index of its physical and mechanical properties at the end of the annealing process, an automatic control system (ACS) of the wire heating temperature is installed. This ACS allows to keep the temperature at a given value, despite the change in the disturbing effects [17].

The functional scheme of ACS is shown in Fig. 3.

In Fig. 3, the primary pyrometer controls the temperature of the wire heating at the control points in a given range. When the heating value is increased, the PID controller generates a reference signal to the power 
controller, which in turn generates the power supply parameters. This operation is inversely proportional. Application of ACS with temperature feedback and current control influence for annealing of wire enables stable operation of the whole system. To avoid overheating, and therefore breakage of the wire, it is recommended to set the limits of the signal of influence (current) at such level to provide a reserve of power to maintain the temperature regime, while preventing the breakdown temperature.

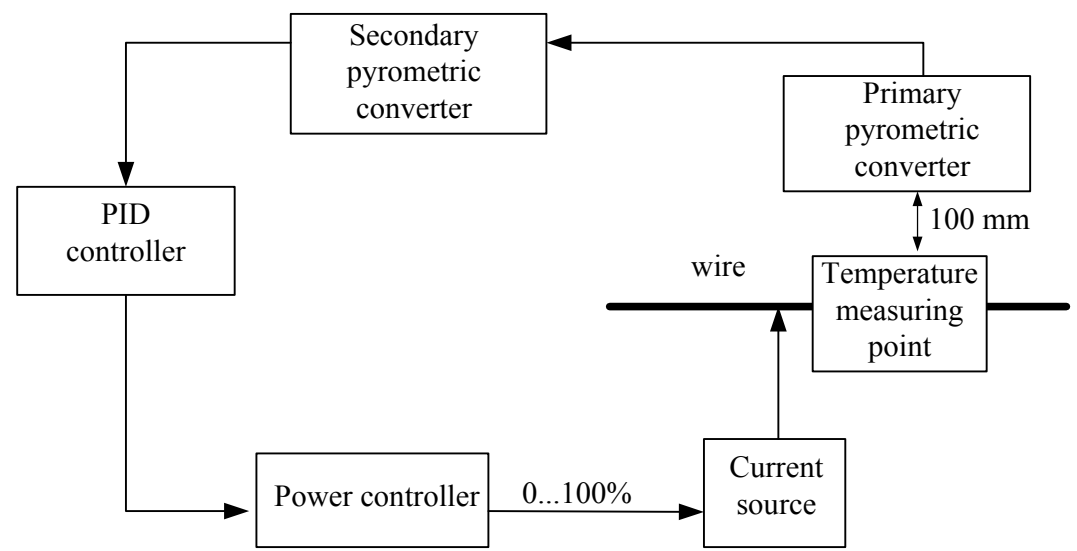

Fig. 3. Functional diagram of the automatic temperature control system for electrocontact annealing

\section{Research results}

Studies are carried out on annealing regimes at the experimental unit of electrocontact annealing and testing of the process of electrocontact heating. As a result of the research work, experimental data are obtained, the analysis of which give grounds for drawing conclusions and developing recommendations for application of electrocontact annealing in the production of steel wire. The modes of experimental annealing of steel wire $\mathrm{CB} 08$ Г2C (diameter $2.5 \mathrm{~mm}$ ) and their results are given in Table 1.

Based on the research results, the following conclusions can be drawn. With an increase in the annealing rate of more than $1 \mathrm{~m} / \mathrm{s}$, it is necessary to pay attention to the use of more powerful electrical devices and, as a result, a significant increase in financial costs to ensure a stable technological process of wire annealing, namely:

- increasing the power of the wire heating source in conjunction with the switching and control elements;

- strengthening the power of the cooling system of the contact rollers;
- change of design parameters of current-conducting mechanical components.

Especially it should be noted that the productivity of electrocontact annealing process at a speed of $1 \mathrm{~m} / \mathrm{s}$ is $136 \mathrm{~kg} / \mathrm{h}$. The value of the power during the annealing of wire with a speed within $1 \mathrm{~m} / \mathrm{s}$, allowing to obtain the temperature limits characteristic of the required mechanical properties of the annealed wire, correspond to $15 \mathrm{kWh}$ per $136.8 \mathrm{~kg}$. That is, energy consumption under these conditions is $0.1 \mathrm{kWh} / \mathrm{kg}$.

After carrying out experimental work to determine the dependence of mechanical characteristics on annealing conditions, it is decided to conduct annealing of the wire in volumes sufficient for further drawing with copper plating. Drawing with subsequent copper-plating to produce a welding wire with a final diameter of $1.6 \mathrm{~mm}$ and $1.2 \mathrm{~mm}$ is performed on the basis of the obtained annealed coil samples $3 \div 7$ (Table 1 ). As a result of determining the operability of the obtained samples of welding wire of both diameters (Tables 2, 3), the following properties are achieved: weldability and welding quality is good, spraying is minimal, copper coating is uniform. On the properties and quality of welding corresponds to the current indicators of serial production.

Table 2

Mechanical characteristics of copper-plate wire with a diameter of $1.6 \mathrm{~mm}$

\begin{tabular}{|c|c|c|}
\hline Sample number & Strength limit, $\mathrm{N} / \mathrm{mm}^{2}$ & Elongation, \% \\
\hline 3 & $1119 \div 1158$ & 3.5 \\
\hline 4 & $1152 \div 1180$ & 3.5 \\
\hline
\end{tabular}

Table 3

Mechanical characteristics of copper-plate wire with a diameter of $1.2 \mathrm{~mm}$

\begin{tabular}{|c|c|c|}
\hline Sample number & Strength limit, $\mathrm{N} / \mathrm{mm}^{2}$ & Elongation, \% \\
\hline 5 & $1268 \div 1310$ & $2.5 \div 3.0$ \\
\hline 6 & $1285 \div 1362$ & $3.0 \div 5.0$ \\
\hline 7 & $1298 \div 1350$ & $2.25 \div 3.0$ \\
\hline
\end{tabular}

The obtained samples 3, 4 (Table 2) and 5 (Table 3) meet the requirements of GOST 2246-70, which are imposed on this product.

Mechanical properties of annealed wire (СВОВГ2Г, diameter $2.5 \mathrm{~mm}$ )

\begin{tabular}{|c|c|c|c|c|c|}
\hline Sample number & Feeding speed, $\mathrm{m} / \mathrm{s}$ & Heating temperature, ${ }^{\circ} \mathrm{C}$ & Strength limit, $\mathrm{N} / \mathrm{mm}^{2}$ & Elongation, \% & Narrowing, \% \\
\hline 1 & 0.4 & 570 & 732.84 & 17.5 & 47 \\
\hline 2 & 1 & 520 & 896.39 & 3 & 36 \\
\hline 3 & 0.6 & 540 & 759.75 & 5.5 & 54 \\
\hline 4 & 0.6 & 510 & 890.17 & 5.5 & 52 \\
\hline 5 & 0.6 & 530 & 768.03 & 5 & 54 \\
\hline 6 & 1.2 & 520 & 861.19 & 2.5 & 55 \\
\hline 7 & 1.2 & 530 & 821.86 & 2.5 & 54 \\
\hline
\end{tabular}


It is experimentally established that after annealing at a diameter of $2.5 \mathrm{~mm}$, the mechanical properties of the wire are obtained in accordance with GOST 2246-70. Also there are no wire breaks while following a further technological route.

The use of the automatic temperature control system made it possible to achieve sufficient homogeneity of the wire, since the oscillations of the time resistance in one coil does not exceed $98 \mathrm{~N} / \mathrm{mm}^{2}$, which is required by GOST 2246-70.

\section{SWOT analysis of research results}

Strengths. Among the strengths of this research, it is necessary to note the obtained results to improve the quality of manufactured products by replacing the intermediate annealing operation in the furnace with electrocontact annealing. This reduces the number of breaks when drawing a copper-plate wire while passing the production route. The application of the developed system of automatic control of temperature modes with the change in speed conditions during the execution of the technological route makes it possible to increase the wire homogeneity in accordance with the requirements of GOST 2246-70. The use of this technology has reduced the rejection of the wire at the output of the drawing operation by $80 \%$, thus reducing the production cost by $40 \%$.

Weaknesses. The weaknesses of this research are related to the fact that when implementing an electrocontact annealing at the production plant, the costs of installing and setting up additional equipment, like the experimental setup shown in Fig. 2.

Opportunities. Additional opportunities lie in the possibility of using this method to improve the quality of other types of products with little adjustment to the automatic control of temperature regimes.

Threats. There is another promising and developing method of annealing-induction heating - heating by an «internal» coolant $[18,19]$. Analysis of this heat treatment method shows that this method allows:

- perform heat treatment in automated production lines;

- significantly reduce the metal waste and practically eliminate decarburization;

- significantly shorten the annealing time.

\section{Conclusions}

1. A rational scheme for the arrangement of electrocontact rollers with respect to the wire is developed, which prevents the wire from slipping off the rollers as it moves and ensuring an even distribution of the tension forces of the wire when drawing. The use of this arrangement of the electrocontact rollers with respect to the wire with the possibility of their cooling ensures the performance of wire heating in accordance with the requirements of the technological process. Namely, uniform heating of the entire wire both on the surface and inside, which will allow drawing the wire into a smaller diameter with a homogeneous structure of the wire material.

2. The values of the mechanical parameters of copper-plate welding wire for the technological route for the production of wire with a diameter of $1.6 \mathrm{~mm}$ with the use of electrocontact annealing are determined:
- ultimate strength $-770 \div 850 \mathrm{~N} / \mathrm{mm}^{2}$;

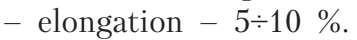

For the production of wire diameters of $1.2 \mathrm{~mm}$ :

- ultimate strength - 700 $\div 770 \mathrm{~N} / \mathrm{mm}^{2}$;

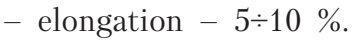

It is shown that the mechanical parameters of a steel wire after electrocontact annealing satisfy the requirements of the GOST for obtained products. These parameters also ensure the stability of the process of further drawing with copper plating without breaking the wire being processed due to the removal of internal stresses in the metal, which are formed during the previous drawing.

3. The necessity of using the automatic temperature control system for electrocontact annealing is confirmed to ensure homogeneity of the fine-grained internal structure of the wire and stable operation of the entire system, by controlling the temperature and controlling the current effect by using feedbacks. ACS prevents overheating and wire breakage.

\section{References}

1. Alimov, V. Physical and mechanical properties of welding wire [Text] / V. Alimov, A. Maksakov, O. Pushkina, D. Ponomarenko // Proceeding of the Donbas National Academy of Civil Engineering and Architecture. - 2013. - Vol. 1, No. 102. P. 94-101.

2. Volochai, O. Perspektivy razvitiia ukrainskogo rynka svarochnogo oborudovaniia i materialov [Electronic resource] / O. Volochai // Stroitel'stvo i rekonstruktsiia. - No. 8. - Available at: \www/URL: http://weldingsite.in.ua/st21.html

3. Provoloka svarochnaia SVO8G2S omednennaia v katushkah i kassetah [Electronic resource] // Megaprom. - Available at: \www/URL: http://www.metizorel.ru/prov2246.html

4. Kazmin, V. P. Sravnitel'nyi analiz sposobov otzhiga provoloki [Text] / V. P. Kazmin // Izvestiia Tomskogo ordena oktiabr'skoi revoliutsii i ordena trudovogo krasnogo znameni politehnicheskogo instituta imeni S. M. Kirova. - 1976. Vol. 266. - P. 59-61.

5. Krupin, A. V. Plasticheskaia deformatsiia tugoplavkih metallov [Text]: Handbook / A. V. Krupin, V. Ya. Solovev. - Moscow: Metallurgiia, 1971. - 350 p.

6. Kudrin, V. A. Teoriia i tehnologiia proizvodstva stali [Text]: Handbook / V. A. Kudrin. - Moscow: Mir, OOO «Izdatelstvo ACT», 2003. - 528 p.

7. GOST 2246-70. Provoloka stal'naia svarochnaia. Tehnicheskie usloviia [Text]. - Introduced: 1973-01-01. - Moscow: Izdatel'stvo standartov, 1973. - 17 p.

8. Artemev, S. Analysis of methods of receipt of continuous fibers of threadlike crystals [Text] / S. Artemev, V. Shaporev // Bulletin of NTU «KhPI». Series: Mechanical-technological systems and complexes. - 2016. - No. 17 (1189). - P. 14-18.

9. Pupan, L. I. Perspektivnye tehnologii polucheniia i obrabotki materialov [Text] / L. I. Pupan, V. I. Kononenko. - Kharkiv: NTU «KhPI», 2008. - 261 p.

10. Belianin, R. V. Analiz vliianiia sposoba izgotovleniia mednoi katanki na harakteristiki mednoi provoloki [Text] / R. V. Belianin // Bulletin of NTU «KhPI». Series: Mechanical-technological systems and complexes. - 2013. - No. 11 (985). P. $175-182$

11. Zapoticla, F. The Effects of Applied Strain and Heat Treatment on the Properties of NiTi Wire During Shape Setting [Text] / F. Zapoticla. - Robert E. Kennedy Library, Cal Poly, 2010. - 111 p. doi:10.15368/theses.2010.143

12. Zybin, I. N. Features of renewal of conical surfaces of details by electrocontact welding of the wire [Text] / I. N. Zybin, A. S. Kovalenko // Science Almanac. - 2016. - No. 6-2 (20). P. 57-63. doi:10.17117/na.2016.06.02.057

13. Cao, J. Effects of Drawing and Annealing on Properties of Ag-4Pd Alloy Bonding Wire [Text] / J. Cao // Journal of Mechanical Engineering. Chinese Journal of Mechanical Engineering. - 2016. - Vol. 52, No. 1. - P. 92-97. doi:10.3901/ jme.2016.18.092 
14. Liashenko, V. P. Opredelenie parametrov upravleniia dvizhush chegosia sosredotochennogo istochnika tepla [Text] / V. P. Liashenko // Bulletin of NTU «KhPI». Series: Mechanical-technologica systems and complexes. - 2013. - No. 16 (989). - P. 177-182.

15. Khrebtov, E. Plication of the frequency controlled electric drive for drawing machine MV-1000V [Text] / E. Khrebtov, A. Kulik // Transactions of Kremenchuk Mykhailo Ostrohradskyi National University. - 2014. - Vol. 6, No. 1 (89). - P. 11-19.

16. Kovrev, G. S. Elektrokontaktnyi nagrev pri obrabotke tsvet nyh metallov [Text] / G. S. Kovrev. - Moscow: Metallurgiia, 1975. - 312 p.

17. Khrebtov, E. Analysis of ways of wire heating in conjunction with the drawing process [Text] / E. Khrebtov // Transactions of Kremenchuk Mykhailo Ostrohradskyi National University. 2015. - Vol. 3 (92). - P. 91-97.

18. Kolpak, V. P. Kompleksnye linii elektrotermicheskoi obrabotki stal'nogo prokata i provoloki [Text] / V. P. Kolpak, A. N. Leshchenko, L. M. Poltoratskii, A. V. Boiarintseva // OTTOM-4. 2003. - Vol. 1. - P. 42-44.

19. Gul, Yu. P. Intensifikatsiia protsessa sferoidiziruiushchego otzhiga stali v potochnyh liniiah [Text] / Yu. P. Gul, M. A. Sobolenko // Stroitelstvo. Materialovedenie. Mashinostroenie. Seriia: Starodubovskie chteniia. - 2011. - Vol. 58. - P. 197-202.
ИССЛЕДОВАНИЕ ЗЛЕКТРОКОНТАКТНОГО ОТЖИГА В ПРОЦЕССЕ ПРОИЗВОДСТВА СТАЛЬНОЙ СВАРОЧНОЙ ПРОВОЛОКИ

Рассмотрены результаты экспериментальных и теоретических исследований по определению условий реализации электроконтактного отжига в процессе производства стальной сварочной проволоки. Показано влияние прямого нагрева током на формирование структуры и изменение механических свойств сварочной проволоки СВ08Г2С. С помощью экспериментальной установки электроконтактного нагрева получены промежуточные значения параметров проволоки, удовлетворяющие условиям дальнейшей обработки проволоки одновременно с соответствием готовой продукции к выдвигаемым требованиям.

Ключевые слова: стальная сварочная проволока, электроконтактный отжиг, механические свойства сварочной проволоки.

Khrebtov Evgeniy, Postgraduate Student, Department of Informatics and Higher Mathematics, Kremenchuk Mykhailo Ostrohradskyi National University, Ukraine, Engineer, State Enterprise «Engineering Center of Hard Alloys «Svetkermet», Svetlovodsk, Kirovograd region, Ukraine, ORCID: http://orcid.org/0000-0002-9594-4260 